\title{
JURR ANI
}

\section{Jurnal Pendidikan Ekonomi}




\title{
JURKAMI: Jurnal Pendidikan Ekonomi
}

http://jurnal.stkippersada.ac.id/jurnal/index.php/JPE

JURKAMI Volume 4, no 1, 2019

\section{PENERAPAN MODEL PEMBELAJARAN TWO STAY TWO STRAY DENGAN MODEL PEMBELAJARAN JIGSA W TERHADAP HASIL BELAJAR KOGNITIF SISWA SMAN 2 SINTANG}

\author{
Elida Dewi Pandini ${ }^{1}$, Dessy Triana Relita ${ }^{2}$ \\ STKIP Persada Khatulistiwa Sintang, Indonesia \\ Email : bebyelida995@gmail.com,dssytriana.relita@gmail.com
}

Diterima: 25 Februari 2019; Disetujui: 28 Maret 2019; Diterbitkan: 1 April 2019

\begin{abstract}
This research aims to find out how the application of the Two Stay Two Stray (TSTS) model and the Jigsaw learning model on students' cognitive learning outcomes in labor issues material in Indonesia. The independent variable of this study is "Two Stay Two Stray learning model (TSTS) and Jigsaw learning model", while the dependent variable is "Learning Outcomes". The research approach used in this research was a quantitative approach. The form of research used in this study was an experiment form with Two Group Pretest Posttest research design. The population in this research were all students of class IX IPS consisting of four classes namely class IX IPS 1, IX IPS 2, IX IPS 3, and IX IPS 4 with the total number of students were 134. The sampling technique used in this study was purposive sampling. Data collection tools used were test questions, observation sheets and documentation. The results showed that There were no significant differences in cognitive learning outcomes between students who used the two stay two stray learning model and the jigsaw learning model with the results of $Z_{-}$(count) of 1.72 and $Z_{-}$(table) at a significant level of 0.05 were 1.96.
\end{abstract}

\section{Keywords: TSTS Learning Model and Jigsaw, Learning Outcome}

Abstrak: Penelitian ini bertujuan untuk melihat bagaimana penerapan model Two Stay Two Stray (TSTS) dengan model pembelajaran Jigsaw terhadap hasil belajar kognitif siswa pada materi permasalahan ketenagakerjaan di indonesia. Variabel bebas penelitian ini adalah "model pembelajaran Two Stay Two Stray (TSTS) dan model pembelajaran Jigsaw", sedangkan variabel terikatnya adalah "Hasil Belajar". Pendekatan penelitian yang digunakan dalam penelitian ini adalah pendekatan kuantitatif. Bentuk penelitian yang digunakan dalam penelitian ini adalah bentuk eksperimen dengan rancangan penelitian Two Group Pretest Posttest Designs. Populasi dalam penelitian ini adalah seluruh siswa kelas IX IPS yang terdiri dari empat kelas yaitu kelas IX IPS 1, IX IPS 2, IX IPS 3, dan IX IPS 4 dengan jumlah keseluruhan siswa yaitu 134. Teknik pengambilan sampel yang digunakan dalam penelitian ini adalah purposive sampling. Alat pengumpulan data yang digunakan adalah soal tes, lembar observasi dan dokumentasi. Hasil penelitian menunjukkan bahwa tidak terdapat perbedaan yang signifikan hasil belajar kognitif antara siswa yang menggunakan model pembelajaran two stay two stray dengan model pembelajaran jigsaw dengan hasil $Z_{\text {hitung }}$ sebesar 1,72 dan $Z_{\text {tabel }}$ pada taraf signifikan 0,05 sebesar 1,96.

\section{Kata kunci: Model Pembelajaran TSTS dan Jigsaw, Hasil belajar}


PENDAHULUAN

Keberhasilan proses belajar mengajar merupakan hal utama yang diharapkan dalam melaksanakan pendidikan di sekolah. Komponen utama dalam kegiatan belajar mengajar adalah siswa yang menjadi subjek belajar, dimana siswa berperan aktif dalam proses pembelajaran sehingga akan menghasilkan pengetahuan, pengalaman, pemahaman dan aspek-aspek lain. Realitanya dalam proses pembelajaran masih sering ditemukan siswa yang kurang aktif, siswa yang hasil belajarnya rendah dan sisiwa tidak memperhatikan guru pada saat mengajar.

Dalam proses pembelajaran seorang guru berharap agar suasana di dalam kelas benar-benar hidup dan semua siswa dapat termotivasi terhadap pelajaran. Guru sebagai pengajar dan pendidik berperan untuk memberikan ilmu yang dimilikinya kepada peserta didik dan memberikan pembinaan yang berhubungan dengan kedisiplinan peserta didik. Di dalam proses pembelajaran guru merupakan penentu keberhasilan belajar peserta didik. Oleh karena itu, guru harus berupaya agar kegiatan di kelas dapat memberikan kesempatan yang luas untuk pengalaman siswa.

Agar kegiatan proses pembelajaran tersebut berlangsung sebaik-baiknya, maka pendidik perlu mengaplikasikan berbagai model, pendekatan, metode dan cara-cara yang tepat agar materi pembelajaran tersampaikan secara efektif dan efisien kepada peserta didik. Salah satu upaya yang dapat dilakukan oleh pendidik dalam kegiatan belajar adalah memilih model pembelajaran kooperatif dan inovatif yang mampu mendorong siswa untuk menemukan dan memahami konsep yang sulit dan dapat mendiskusikan dan menyelesaikan masalah-masalah pembelajaran bersama teman sebayanya dengan baik.

Berdasarkan hasil pra penelitian yang dilakukan oleh peneliti dengan mewawancarai seorang guru ekonomi kelas XI SMA Negeri 2 Sintang mengatakan bahwa dalam pelakasanaan proses pembelajaran ekonomi di kelas XI guru pernah menggunakan model pembelajaran Problem Based Learning (PBL) tetapi model pembelajaran tersebut belum mampu mengajak siswa secara maksimal untuk aktif dalam proses pembelajaran, masih ada siswa yang sibuk sendiri pada saat belajar di kelas, karena pada kenyataan yang kita ketahui bahwa karakter dari setiap siswa berbeda-beda dalam belajar sehingga nilai dari siswa akan berbeda pada setiap materi dengan perubahan model yang digunakan oleh guru pada saat mengajar. Sehingga hal tersebut menjadi penyebab nilai siswa masih ada yang belum mencapai Kiteria 
Ketuntasan Minimal (KKM) yang sudah ditentukan yaitu 75. Hal tersebut memang tidak bisa kita pungkiri karena memang kita tahu bahwa setiap siswa memiliki tingkat kemampuan yang berbeda-beda dalam belajar tetapi hal tersebut bisa kita minimalisir dengan menerapkan berbagai model pembelajaran yang bisa meningkatkan keaktifan siswa dalam proses pembelajaran. Ada beberapa model yang bisa kita gunakan dalam proses pembelajaran di kelas diantaranya yaitu model pembelajaran Two Stay Two Stray dan Jigsaw.

$$
\text { Peneliti ingin mencoba }
$$
menerapkan model pembelajaran Two Stay Two Stray dan Jigsaw dalam menyajikan materi permasalahan ketenagakerjaan di Indonesia, karena dalam materi permasalahan ketenagakerjaan di Indonesia ini terdiri dari beberapa sub bab yang cocok untuk digunakan dengan kerja tim, pemberian argumen/ide, dan bertukar pengetahuan/sharing sesuai dengan karakteristik dari model-model tersebut. Jadi dalam penelitian ini peneliti ingin melihat bagaimana proses belajar siswa dalam memahami materi pasar modal, sehingga dalam penelitian ini peneliti menggunakan model pembelajaran Two Stay Two Stray dan Jigsaw.

Untuk permasalahan yang sudah dikemukakan diatas di dukung dari penelitian terdahulu. Hasil penelitian
Wahyuni dan Munthe (2014) dengan judul penelitian "Pengaruh Model Pembelajaran Kooperatif Tipe Two Stay Two Stray (TSTS) terhadap Hasil Belajar Siswa pada Materi Listrik Dinamis pada Siswa SMA". Hasil pengujian hipotesis diperoleh $t_{\text {hitung }}>$ $\mathrm{t}_{\text {tabel }}$ yaitu 2,326 $>2,006$ dengan $\alpha=0,05$ dan $\mathrm{dk}=54$, maka Ha diterima yang berarti ada perbedaan akibat pengaruh model pembelajaran Kooperatif Tipe $T w o$ Stay Two Stray dengan model pembelajaran konvensional terhadap hasil belajar siswa pada materi Listrik Dinamis di kelas X SMA Negeri 3 Tebing Tinggi Tahun Pelajaran 2012/2013.

Trisianawati dkk (2016) dengan judul penelitian "Pengaruh Model Pembelajaran Kooperatif Tipe Jigsaw terhadap Hasil Belajar Siswa pada Materi Vektor Di Kelas X SMA Negeri 1 Sanggau Ledo". Dari hasil analisis data menggunakan uji Mann Whitney dapat disimpulkan bahwa terdapat perbedaan hasil belajar siswa yang diajarkan dengan pembelajaran kooperatif Tipe Jigsaw dengan siswa yang diajarkan dengan pembelajaran diskusi-ceramah pada materi vektor. (4). Dari hasil analisis data menggunakan effect size diperoleh nilai effect size sebesar 0,44. Dapat disimpulkan bahwa penerapan model pembelajaran Kooperatif Tipe Jigsaw cukup berpengaruh terhadap peningkatan hasil belajar siswa pada materi vektor di kelas $\mathrm{X}$ 
SMA Negeri 1 Sanggau Ledo. Dari beberapa penelitian diatas membuktikan bahwa penerapan model pembelajaran Two Stay Two Stray dan Jigsaw dapat memperbaiki hasil belajar siswa.

Berdasarkan masalah tersebut maka tujusn penelitian ini adalah untuk mengetahui penerapan model pembelajaran two stay two stray (TSTS) dengan model pembelajaran jigsaw terhadap hasil belajar kognitif siswa pada materi permasalahan ketenagakerjaan di Indonesia (Studi Eksperimen Di Kelas XI SMA Negeri 2 Sintang Tahun Pelajaran 2018/2019).

\section{KAJIAN TEORI}

Model pembelajaran kooperatif tipe TSTS kali pertama dikembangkan oleh Spencer Kagan 1992. TSTS berasal dari bahasa Inggris yang berarti dua tinggal dua tamu. Teknik ini memberi kesempatan kepada siswa untuk membagikan hasil informasi dengan kelompok lain. Suyatno (Fathurrohman 2015: 90) "Model pembelajaran kooperatif tipe TSTS adalah dengan cara siswa berbagi pengetahuan dan pengalaman dengan kelompok lain". Sintaknya adalah kerja kelompok, dua siswa bertamu ke kelompok lain dan dua siswa lainnya tetap dikelompoknya untuk menerima dua orang dari kelompok lain, kerja kelompok, kembali ke kelompok asal, kerja kelompok, dan laporan kelompok.

Suprijono (Fathurrohman 2015:

90), mengatakan bahwa:

Model pembelajaran kooperatif tipe TSTS atau dua tinggal dua tamu di awali dengan pembagian kelompok. Setelah kelompok terbentuk, guru memberikan tugas berupa permasalahan-permasalahan yang harus mereka diskusikan jawabannya. Setelah diskusi intrakelompok selesai, dua orang dari masing-masing kelompok meninggalkan kelompoknya untuk bertamu ke kelompok lain. Anggota kelompok yang tidak mendapat tugas sebagai duta (tamu) mempunyai kewajiban menerima tamu dari suatu kelompok. Tugas mereka adalah menyajikan hasil kerja kelompoknya kepada tamu tersebut. Dua orang yang bertugas sebagai tamu diwajibkan bertamu kepada semua kelompok. Jika mereka telah selesai melaksanakan tugasnya, mereka kembali ke kelompoknya masing-masing. Setelah kembali ke kelompok asal, baik siswa yang bertugas bertamu maupun mereka yang bertugas menerima tamu mencocokkan dan membahas hasil kerja yang telah mereka tunaikan.

Berdasarkan teori di atas peneliti menyimpulkan model pembelajaran kooperatif tipe TS-TS sebagai salah satu model pembelajaran kooperatif yang memberikan kesempatan untuk bertukar hasil diskusi antara satu kelompok dengan kelompok yang lain untuk kemudian membuat kesimpulan berdasarkan kecocokkan hasil diskusi 
antara kelompok pertama dengan

kelompok yang dikunjunginya.

Langkah-langkah model pembelajaran Two Stay Two Stray

(TSTS) sebagai berikut:

a. Guru menyampaikan materi pelajaran atau permasalahan kepada siswa sesuai dengan kompetensi dasar yang akan dicapai.

b. Guru membentuk beberapa kelompok. Setiap kelompok terdiri dari 4-5 orang siswa secara heterogen dengan kemampuan berbeda-beda baik tingkat kemampuan (tinggi, sedang, dan rendah) maupun jenis kelamin.

c. Guru memberikan Lembar Kerja Siswa (LKS) atau tugas untuk dibahas dalam keompok.

d. Siswa 2-3 orang dari tiap kelompok berkunjung ke kelompok lain untuk mencatat hasil pembahasan LKS atau tugas dari kelompok lain, dan sisa kelompok tetap di kelompoknya untuk menerima siswa yang bertamu ke kelompoknya.

e. Siswa yang bertamu kembali ke kelompoknya masing-masing dan menyampaikan hasil kunjungannya kepada teman yang tetap berada dalam kelompok. Hasil kunjungan dibahas bersama dan dicatat.

f. Hasil diskusi kelompok dikumpulkan dan salah satu kelompok mempresentasikan jawaban mereka, kelompok lain memberikan tanggapan.

g. Guru memberikan klarifikasi terhadap jawaban yang benar.

h. Guru membimbing siswa merangkum pelajaran.

i. Guru memberikan penghargaan secara kelompok.

Kelebihan dan kekurangan

model pembelajaran Two Stay Two
Stray (TSTS) dalam Fathurrohman

(2015:91) sebagai berikut:

Kelebihan model pembelajaran TSTS adalah dapat digunakan dalam semua mata pelajaran dan semua tingkat usia siswa. Model ini tidak hanya bekerja sama dengan anggota sekelompok, tetapi bisa juga bekerja sama dengan kelompok lain yang memungkinkan terciptanya keakraban sesama teman dalam satu kelas dan lebih berorientasi pada keaktifan siswa. Sementara itu.

Kekurangan dari model pembelajaran TSTS ini adalah jumlah siswa dalam satu kelas tidak boleh ganjil harus berkelipatan empat, peralihan dari seluruh kelas ke kelompok kecil, dan kunjungan dari dua orang anggota kelompok yang satu ke kelompok lain membutuhkan perhatian khusus dalam pengelolaan kelas serta dapat menyita waktu pengajaran yang berharga. Selain itu guru juga harus membutuhkan banyak persiapan.

$$
\text { Rusman }
$$

mengungkapkan bahwa:

Arti Jigsaw dalam bahasa Inggris adalah gergaji ukir dan ada juga yang menyebutnya dengan istilah puzzle yaitu sebuah teka-teki menyusun potongan gambar. Pembelajaran kooperatif model Jigsaw ini mengambil pola cara kerja sebuah gergaji (zigzag), yaitu siswa yang melakukan suatu kegiatan belajar dengan cara bekerja sama dengan siswa lain untuk mencpai tujuan bersama. 
Pada dasarnya, dalam model ini guru membagi suatu informasi yang besar menjadi komponen-komponen lebih kecil. Selanjutnya guru membagi siswa ke dalam kelompok belajar kooperatif yang terdiri dari empat orang siswa sehingga setiap anggota bertanggung jawab terhadap penguasaan setiap komponen/subtopik yang ditugaskan guru dengan sebaiksebaiknya. Siswa dari masing-masing kelompok yang bertanggung jawab terhadap subtopik yang sama membentuk kelompok lagi yang terdiri atas dua atau tiga orang.

Langkah-langkah model pembelajaran jigsaw dalam Rusman (2013: 218) sebagai berikut:

a. Siswa dikelompokkan dengan anggota \pm 4 orang;

b. Tiap anggota dalam tim diberi materi dan tugas yang berbeda;

c. Anggota dari tim yang berbeda dengan penugasan yang sama membentuk kelompok baru (kelompok ahli);

d. Setelah kelompok ahli berdiskusi, tiap anggota kembali ke kelompok asal dan menjelaskan kepada anggota kelompok tentang subbab yang mereka kuasai;

e. Tiap tim ahli mempresentasikan hasil diskusi;

f. Pembahasan;

g. Penutup.

Kelebihan dan kekurangan model pembelajaran jigsaw menurut Jhonson dan Johnson (Rusman 2013:219) kelebihan dan kekurangan model pembelajaran kooperatif tipe jigsaw sebagai berikut:
1) Kelebihan model pembelajaran Jigsaw: meningkatkan hasil belajar; meningkatkan daya ingat, dapat digunakan untuk mencapai taraf penalaran tingkat tinggi; mendorong tumbuhnya motivasi intrinsik (kesadaran individu); meningkatkan hubungan antara manusia yang heterogen; meningkatkan sikap anak yang positif terhadap sekolah; meningkatkan sifat positif terhadap guru; meningkatkan harga diri anak; meningkatkan perilaku penyesuaian sosial yang positif; meningkatkan keterampilan hidup dalam bergotong-royong.

2) Kekurangan model pembelajaran jigsaw: Kegiatan belajar mengajar membutuhkan lebih banyak waktu dibanding metode lain, Bagi guru metode ini memerlukan kemampuan lebih karena setiap kelompok membutuhkan penanganan yang berbeda.

Hasil belajar merupakan kompetensi yang ingin dicapai setelah mengikuti proses belajar. Seseorang dikatakan berhasil dalam belajar apabila terjadi perubahan dalam dirinya seperti perubahan dalam segi keterampilan, sikap, dan kebiasaan baru lainnya. Hal ini sesuai dengan pendapat Hamalik (2009: 80) yang mengatakan bahwa "Hasil belajar adalah terjadinya perubahan tingkah laku dari orang tersebut dari tidak tahu menjadi tahu dan dari tidak mengerti menjadi mengerti. Tingkah laku memiliki unsur subjektif (rohaniah) dan amotoris (jasmaniah). 
Benyamin S Bloom (Sudjana 2016:

49) hasil belajar dapat diklasifikasikan menjadi tiga ranah yaitu ranah kognitif, afektif dan psikomotorik.

1) Ranah kognitif berkenaan dengan hasil belajar intelektual yang terdiri dari enam aspek yaitu pengetahuan atau ingatan, pemahaman, aplikasi, analisis, sintesis dan evaluasi.

2) Ranah afektif yang berkenaan dengan sikap yang terdiri dari lima aspek yaitu penerimaan, jawaban atau reaksi, penialaian organisasi dan internalisasi.

3) Ranah psikomotorik berkenaan dengan hasil belajar keterampilan dan kemampuan bertindak. Ada enam ranah psikomotorik

4) yakni gerak refleks, keterampilan, gerakan dasar, kemampuan perfektual, keharmonisan atau ketepatan, gerakan keterampilan kompleks.

Ketiga ranah tersebut menjadi objek penilaian hasil belajar, diantara ketiga ranah tersebut ranah kognitiflah yang paling banyak dinilai oleh guru disekolah karena berkaitan dengan kemampuan siswa dalam memahami bahan pelajaran. Sudjana (2016: 22) meyatakan bahwa hasil belajar adalah "kemampuan yang dimiliki siswa setelah ia menerima pengalaman belajarnya". Kemampuan menyangkut domain kognitif, afektif dan psikomotorik. Daryanto (Fatmawati 2015: 13) mengatakan bahwa "dalam hubungan dengan satuan pelajaran, ranah kognitif memegang peranan paling utama". Ranah kognitif menggolongkan dan mengurutkan keahlian berpikir yang menggambarkan tujuan yang diharapkan. Proses berpikir mengekspresikan tahap-tahap kemampuan yang harus siswa kuasai sehingga dapat menunjukkan kemampuan mengolah pikirannya sehingga mampu mengaplikasikan teori ke dalam perbuatan. Mengubah teori ke dalam keterampilan terbaiknya sehingga dapat menghasilkan sesuatu yang baru sebagai produk inovasi pikirannya

\section{METODE PENELITIAN}

Berdasarkan tujuan yang hendak dicapai, maka dalam penelitian ini penulis menggunakan metode kuantitatif. Sugiyono (2014: 8) "Metode penelitian kuantitatif digunakan untuk meneliti pada populasi atau sampel tertentu, pengumpulan data menggunakan instrumen penelitian, analisis data bersifat kuantitatif/statistik, dengan tujuan untuk menguji hipotesis yang telah ditetapkan". Metode penelitian yang digunakan adalah Pre-Experimental Designs. PreExperimental Designs, yaitu desain yang belum merupakan eksperimen sungguhsungguh karena masih terdapat variabel luar yang ikut berpengaruh terhadap terbentuknya variabel dependen. Jadi hasil eksperimen yang merupakan variabel dependen itu bukan semata-mata dipengaruhi oleh variabel independen.

Desain penelitian yang digunakan yaitu Two Group, Pretests Posttest Design. Desain penelitian ini menggunakan dua 
54 | Elida Dewi Pandini, Dessy Triana Relita, Penerapan Model Pembelajaran

kelas dimana kedua kelas tersebut keberhasilan pembelajaran. Adapun dijadikan sebagai kelas eksperimen. Two gambaran desain penelitian Two Group, Group, Pretests Posttest Design diberikan $\quad$ Pretests Posttest Design sebagai berikut pretest-posttest untuk dijadikan tolak ukur

Tabel 1 Two Group, Pretests Posttest Design

\begin{tabular}{lclc}
\hline Kelas & Pretest & Perlakuan & Posttest \\
\hline Kelas TSTS & $O_{1}$ & $\mathrm{X}$ & $O_{2}$ \\
\hline Kelas Jigsaw & $O_{3}$ & $\mathrm{X}$ & $O_{4}$ \\
\hline
\end{tabular}

\section{Keterangan:}

$\begin{array}{ccl}\mathrm{O}_{1} & : & \text { Tes awal (pretest) kelas eksperimen I } \\ \mathrm{O}_{3} & : & \text { Tes awal (pretest) kelas eksperimen II } \\ X & : & \text { Model pembelajaran two stay two stray } \\ X & : & \text { Model pembelajaran jigsaw } \\ \mathrm{O}_{2} & : & \text { Tes akhir (posttest) kelas eksperimen I } \\ \mathrm{O}_{4} & : & \text { Tes akhir (posttest) kelas eksperimen II }\end{array}$

Populasi penelitian adalah siswa kelas XI IPS SMA Negeri 2 Sintang yang terdiri dari empat kelas dengan jumlah siswa 134 orang. Sampel penelitian adalah siswa kelas XI IPS 1 dan XI IPS 2, teknik pengambilan sampel pada penelitian ini dilakukan secara Purposive Sampling. Kelas XI IPS 1 merupakan kelas eksperimen 1 dan kelas XI IPS 2 merupakan kelas eksperimen 2.

Pengumpulan data dilakukan untuk memperoleh informasi yang dibutuhkan dalam rangka mencapai tujuan penelitian. Sugiyono (2014: 224) “Teknik pengumpulan data merupakan langkah yang paling strategis dalam penelitian, karena tujuan utama dari penelitian adalah mendapatkan data". Dalam penelitian ini, teknik-teknik yang digunakan sebagai berikut: (1) Teknik Pengukuran, (2)

Teknik Observasi Nonpartisipan,

Teknik Dokumentasi. Alat pengumpulan data dalam penelitian ini yaitu: (1) Soal Tes, (2) Lembar Observasi,

Dokumentasi. Analisis data yang digunakan dalam penelitian ini yaitu menggunakan uji prasyarat yaitu: (1) Uji Normalitas, (2) Uji homogenitas, (3) Uji Hipotesis yaitu Uji Z, (4) Uji Indeks Gain Hake.

\section{HASIL DAN PEMBAHASAN}

Berdasarkan hasil yang didapat oleh peneliti ketika melakukan penelitian pada kelas XI IPS Sekolah Menengah Atas Negeri 02 Sintang tahun pelajaran 2018/2019 menunjukkan bahwa: 
1. Penggunaan model pembelajaran two stay two stray di kelas eksperimen 1 dan model pembelajaran jigsaw di kelas eksperimen 2.

Observasi guru dilakukan pada saat berlangsungnya proses pembelajaran baik itu di kelas eksperimen 1 maupun kelas eksperimen 2. Kegiatan observasi ini melibatkan guru mata pelajaran Ekonomi sebagai observer dan peneliti sebagai pelaksana dalam proses belajar mengajar. Berdasarkan hasil analisis observasi guru di kelas eksperimen 1 pada pertemuan pertama diperoleh hasil persentase $96 \%$, pertemuan kedua $100 \%$ rata-rata pertemuan pertama dan kedua 98\% masuk kategori Sangat baik sedangkan di kelas eksperimen 2 pada pertemuan pertama diperoleh persentase $100 \%$, pertemuan kedua $100 \%$ rata-rata pertemuan pertama dan kedua $100 \%$ masuk kategori Sangat Baik.

Berdasarkan hasil observasi siswa yang diamati oleh dua orang observer dengan jumlah siswa kelas eksperimen 1 berjumlah 32 siswa dan kelas eksperimen 2 berjumlah 30 siswa, diperoleh hasil persentase keterlaksanaan kegiatan pembelajaran pada pertemuan pertama di kelas eksperimen 1 adalah 92,89\%, pada pertemuan kedua mencapai 97,30\% rata-rata pertemuan pertama dan kedua adalah $95,10 \%$ sedangkan hasil observasi siswa kelas eksperimen 2 pada pertemuan pertama adalah $92,87 \%$, pada pertemuan kedua mencapai $97,57 \%$ rata-rata pertemuan pertama dan kedua adalah 95,22\% .

Tidak terdapat perbedaan hasil belajar siswa menggunakan model pembelajaran two stay two stray dan model pembelajaran jigsaw di kelas eksperimen 1 dan eksperimen 2 pada pengukuran awal (pretest).

Sebelum sampel penelitian diberikan perlakuan, terlebih dahulu guru memberikan tes awal (pretest) kepada siswa kelas XI IPS 1 sebagai kelas eksperimen 1 yang berjumlah 32 orang. Tes awal (pretest) pada kelas eksperimen 1 memperoleh nilai tertinggi adalah 70 dan nilai terendah adalah 40, dengan rata-rata pretest kelas eksperimen 1 adalah 58,83. Sedangkan pada kelas eksperimen 2 yang berjumlah 30 orang. Pada pengukuran awal (pretest) memperoleh nilai tertinggi 70 dan nilai terendah 50 dengan rata-rata nilai pretest di kelas eksperimen 2 adalah 62,33.

Uji hipotesis yang digunakan pada penelitian ini yaitu uji parametrik karena data nilai kahir dari kedua kelas tersebut berdistribusi normal dan homogen. Sampel yang digunakan oleh peneliti sebanyak 32 siswa pada kelas 
eksperimen 1 dan 30 siswa pada kelas eksperimen 2. Langkah selanjutnya menggunakan Uji Z karena sampel yang digunakan $\geq 30$. Pada uji $\mathrm{Z}$ didapat nilai $Z_{\text {hitung }}$ adalah 1,84 sedangkan nilai $Z_{\text {tabel }}$ pada taraf signifikan 0,05 dengan nilai sebesar 1,96. Hal ini berarti nilai $t_{\text {hitung }}<\mathrm{t}_{\text {tabel }}$ yaitu $1,84<1,96$ maka $\mathrm{H}_{0}$ diterima dan Ha ditolak. Artinya tidak terdapat perbedaan hasil belajar siswa kelas eksperimen 1 yang menerapkan model pembelajaran two stay two stray dan kelas eksperimen 2 yang menerapkan model pembelajaran jigsaw pada pengukuran awal (pretest).

2. Tidak terdapat perbedaan hasil belajar sisawa kelas eksperimen 1 dan kelas eksperimen 2 setelah menerapkan model pembelajaran two stay two stray dengan model pembelajaran jigsaw pada pengkuran akhir (posttest).

Setelah sampel penelitian diberikan perlakuan, maka selanjutnya guru memberikan tes akhir (posttest) kepada siswa kelas XI IPS 1 sebagai kelas eksperimen 1 yang berjumlah 32 orang. Tes akhir (posttest) pada kelas eksperimen 1 memperoleh nilai tertinggi adalah 95 dan nilai terendah adalah 75 , dengan rata-rata posttest kelas eksperimen 1 adalah 82,19. Sedangkan pada kelas eksperimen 2 yang berjumlah 30 orang. Pada pengukuran akhir (posttest) memperoleh nilai tertinggi 95 dan nilai terendah 70 dengan rata-rata nilai posttest di kelas eksperimen 2 adalah 85,17 .

Uji hipotesis yang digunakan pada penelitian ini yaitu uji parametrik karena data nilai kahir dari kedua kelas tersebut berdistribusi normal dan homogen. Sampel yang digunakan oleh peneliti sebanyak 32 siswa pada kelas eksperimen 1 dan 30 siswa pada kelas eksperimen 2. Langkah selanjutnya menggunakan Uji Z karena sampel yang digunakan $\geq 30$. Pada uji $\mathrm{Z}$ didapat nilai $Z_{\text {hitung }}$ adalah 1,72 sedangkan nilai $Z_{\text {tabel }}$ pada taraf signifikan 0,05 dengan nilai sebesar 1,96. Hal ini berarti nilai $t_{\text {hitung }}<t_{\text {tabel }}$ yaitu $1,72<1,96$ maka $\mathrm{H}_{0}$ diterima dan Ha ditolak. Artinya tidak terdapat perbedaan hasil belajar siswa kelas eksperimen 1 yang menerapkan model pembelajaran two stay two stray dan kelas eksperimen 2 yang menerapkan model pembelajaran jigsaw pada pengukuran akhir (posttest).

3. Terdapat perbedaan hasil belajar siswa sebelum dan setelah pembelajaran menggunakan model two stay two stray di kelas eksperimen 1 ( pretest dan posttest) 
Sebelum sampel penelitian diberikan perlakuan, terlebih dahulu guru memberikan tes awal (pretest) kepada siswa kelas XI IPS 1 sebagai kelas eksperimen 1 yang berjumlah 32 orang. Tes awal (pretest) pada kelas eksperimen 1 memperoleh nilai tertinggi adalah 70 dan nilai terendah adalah 40, dengan rata-rata pretest kelas eksperimen 58,83. Pengukuran awal (pretest) nilai siswa tidak mencapai KKM yang telah ditetapkan yaitu 75 . Pada tes akhir (posttest) di kelas eksperimen 1 memperoleh nilai tertinggi adalah 95 dan nilai terendah adalah 75 , dengan nilai rata-rata tes akhir (posttest) sebesar 82,00. Analisis hasil tes menunjukkan bahwa nilai seluruh siswa pada kelas eksperimen 1 pada pengukuran akhir (posttest) telah mencapai Kriteria Ketuntasan Minimal (KKM) yaitu 75. Besarnya perbedaan hasil belajar siswa kelas eksperimen 2 pada pengukuran awal (pretest) dan pengukuran akhir (posttest) adalah 0,64 dengan kategori baik.

Uji hipotesis yang digunakan pada penelitian ini yaitu uji parametrik karena data nilai kahir dari kedua kelas tersebut berdistribusi normal dan homogen. Sampel yang digunakan oleh peneliti sebanyak 32 orang siswa. Langkah selanjutnya menggunakan Uji $\mathrm{Z}$ karena sampel yang digunakan $\geq 30$.
Pada uji $\mathrm{Z}$ didapat nilai $\mathrm{Z}_{\text {hitung }}$ adalah 13,92 sedangkan nilai $\mathrm{Z}_{\text {tabel }}$ pada taraf signifikan 0,05 dengan nilai sebesar 1,96. Hal ini berarti nilai $t_{\text {hitung }}<t_{\text {tabel }}$ yaitu $13,92<1,96$ maka $\mathrm{H}_{0}$ ditolak dan Ha diterima yang artinya terdapat perbedaan hasil belajar siswa kelas eksperimen 1 pada pengukuran awal (pretest) dan pengukuran akhir (posttest) pada materi permasalahan ketenagakerjaan di Indonesia. Yang artinya hasil belajar siswa sebelum menerapkan model pembelajaran TSTS masih rendah sedangkan setelah menerapkan model TSTS hasil belajar siswa mengalami kenaikan.

4. Terdapat perbedaan hasil belajar siswa sebelum dan setelah pembelajaran menggunakan model jigsaw di kelas eksperimen 2 ( pretest dan posttest).

Tes awal (pretest) pada kelas eksperimen 2 memperoleh nilai tertinggi adalah 70 dan nilai terendah adalah 50, dengan rata-rata pretest 62,33. Pengukuran awal (pretest) nilai siswa tidak mencapai KKM yang telah ditetapkan yaitu 75. Pada tes akhir (posttest) di kelas eksperimen 2 memperoleh nilai tertinggi adalah 95 dan nilai terendah adalah 70 , dengan nilai rata-rata tes akhir (posttest) sebesar 85,17. Besarnya perbedaan hasil belajar siswa kelas eksperimen 2 pada pengukuran awal (pretest) dan 
pengukuran akhir (posttest) adalah 0,69 dengan kategori baik.

Uji hipotesis yang digunakan pada penelitian ini yaitu uji parametrik karena data nilai kahir dari kedua kelas tersebut berdistribusi normal dan homogen. Sampel yang digunakan oleh peneliti sebanyak 30 orang siswa. Langkah selanjutnya menggunakan Uji Z karena sampel yang digunakan $\geq 30$. Pada uji $\mathrm{Z}$ didapat nilai $\mathrm{Z}_{\text {hitung }}$ adalah 12,70 sedangkan nilai $Z_{\text {tabel }}$ pada taraf signifikan 0,05 dengan nilai sebesar 1,96. Hal ini berarti nilai $t_{\text {hitung }}<t_{\text {tabel }}$ yaitu $12,70<1,96$ maka $\mathrm{H}_{0}$ ditolak dan $\mathrm{Ha}$ diterima yang artinya terdapat perbedaan hasil belajar siswa kelas eksperimen 2 pada pengukuran awal (pretest) dan pengukuran akhir (posttest) pada materi permasalahan ketenagakerjaan di Indonesia. Yang artinya hasil belajar siswa sebelum menerapkan model pembelajaran jigsaw masih rendah sedangkan setelah menerapkan model jigsaw hasil belajar siswa mengalami kenaikan.

5. Tidak terdapat perbedaan hasil belajar sisawa kelas eksperimen 1 dan kelas eksperimen 2 pada pengukuran awal (pretest) pengkuran akhir (posttest).

Uji hipotesis yang digunakan pada penelitian ini yaitu uji parametrik karena data nilai pada pengukuran awal (pretest) dan pengukuran akhir (posttest) dari kedua kelas tersebut berdistribusi normal dan homogen. Sampel yang digunakan oleh peneliti sebanyak 32 siswa pada kelas eksperimen 1 dan 30 siswa pada kelas eksperimen 2. Pada kelas eksperimen 1 pada pengukuran awal (pretest) didapat nilai tertinggi 70 dan pada pengukuran akhir (posttest) didapat nilai tertinggi 95, dengan rata-rata nilai pretestposttest pada kelas eksperimen 1 yaitu 70,63. Sedangkan di kelas eksperimen 2 pada pengukuran awal (pretest) didapat nilai tertinggi 70 dan pengukuran akhir (posttest) didapat nilai tertinggi 95, dengan rata-rata nilai pretest-posttest pada kelas eksperimen 2 yaitu 73,75. Langkah selanjutnya untuk melihat perbedaan nilai antara kelas eksperimen 1 dan kelas eksperimen 2 akan dihitung menggunakan Uji Z karena sampel yang digunakan $\geq 30$.

Pada uji $\mathrm{Z}$ didapat nilai $\mathrm{Z}_{\text {hitung }}$ adalah 0,92 sedangkan nilai $Z_{\text {tabel }}$ pada taraf signifikan 0,05 dengan nilai sebesar 1,96. Hal ini berarti nilai $t_{\text {hitung }}<t_{\text {tabel }}$ yaitu 0,92 $<$ 1,96 maka $\mathrm{H}_{0}$ diterima dan Ha ditolak. Artinya tidak terdapat perbedaan yang signifikan hasil belajar siswa kelas eksperimen 1 yang menerapkan model pembelajaran two stay two stray dan kelas eksperimen 2 yang menerapkan model 
JURKAMI: Jurnal Pendidikan Ekonomi

pembelajaran jigsaw pada pengukuran awal (pretest) dan pengukuran akhir (posttest)

\section{PENUTUP}

Berdasarkan analisis data yang telah dilakukan untuk menjawab rumusan masalah dan hipotesis mengenai Penerapan Model Pembelajaran Two Stay Two Stray (TSTS) Dengan Model Pembelajaran Jigsaw terhadap Hasil Belajar Kognitif Siswa Pada Materi Permasalahan Ketenagakerjaan di Indonesia (Studi Eksperimen Di Kelas XI SMA Negeri 2 Sintang Tahun Pelajaran 2018/2019) dapat ditarik kesimpulan sebagai berikut.

1. Proses pembelajaran menggunakan model pembelajaran two stay two stray di kelas eksperimen 1 dan model pembelajaran jigsaw di kelas eksperimen 2 Sekolah Menengah Atas 2 Sintang tahun pelajaran 2018/2019 sudah berjalan dengan baik.

2. Tidak terdapat perbedaan hasil belajar siswa kelas eksperimen 1 dan kelas eksperimen 2 pada pengukuran awal (pretest) pada materi permasalahan ketenagakerjaan di Indonesia di Sekolah Menengah Atas Negeri 02 Sintang dengan hasil $\mathrm{Z}_{\text {hitung }}$ sebesar 1,84 dan $Z_{\text {tabel }}$ pada taraf signifikan 0,05 sebesar 1,96 .

3. Tidak terdapat perbedaan hasil belajar kognitif kelas eksperimen 1 dan kelas
JURKAMI Volume 4, no 1, 2019 | 59

eksperimen 2 pada pengukuran akhir (posttest) pada materi permasalahan ketenagakerjaan di Indonesia dengan hasil $Z_{\text {hitung }}$ sebesar 1,72 dan $Z_{\text {tabel }}$ pada taraf signifikan 0,05 sebesar 1,96.

4. Terdapat perbedaan hasil belajar siswa kelas eksperimen 1 pada pengukuran awal (pretest) dan pengukuran akhir (posttest) pada materi permasalahan ketenagakerjaan di Indonesia dengan hasil $Z_{\text {hitung }}$ sebesar 13,92 dan $Z_{\text {tabel }}$ pada taraf signifikan 0,05 sebesar 1,96.

5. Terdapat perbedaan hasil belajar siswa kelas eksperimen 2 pada pengukuran awal (pretest) dan pengukuran akhir (posttest) pada materi permasalahan ketenagakerjaan di Indonesia dengan hasil $\mathrm{Z}_{\text {hitung }}$ sebesar 12,70 dan $\mathrm{Z}_{\text {tabel }}$ pada taraf signifikan 0,05 sebesar 1,96.

Tidak terdapat perbedaan yang signifikan hasil belajar kognitif antara siswa yang menggunakan model pembelajaran two stay two stray dengan model pembelajaran jigsaw pada pengukuran awal (pretest) dan pengukuran akhir (posttest) di kelas XI SMA Negeri 2 Sintang dengan hasil $Z_{\text {hitung }}$ sebesar 0,92 dan $\mathrm{Z}_{\text {tabel }}$ pada taraf signifikan 0,05 sebesar 1,96

\section{DAFTAR PUSTAKA}

Arifin, Z. 2017. Evaluasi Pembelajaran. Bandung : Rosdakarya offset. 
Arikunto, S. 2010. Prosedur Penelitian Suatu Pendekatan Praktik. Jakarta: Rineka Cipta.

Idrus, C. 2013. "Perbedaan Hasil Belajar Siswa Menggunakan Model Pembelajaran Tipe Talking Stick Dengan Pembelajaran Konvensional Padamata Pelajaran Ekonomi Siswa Kelas X Sman 1 Bonjol Kabupaten Pasaman". Journal of Economic and Economic Education. Volume 2 No. 1 Hal 77- 84

Fathurrohman, M. 2015. Model-model pembelajaran Inovatif. Jogjakarta: Ar-Ruzz Media.

Gayatri, E. P. R., dkk. 2017. "Perbandingan Penerapan Model Pembelajaran Learning Cycle (5e) dan Two Stay Two Stray". Jurnal Pendidikan dan Ilmu Kimia. Volume 1 No. 1 Hal 71-74.

Kumape, S. 2015. "Pengaruh Penerapan Model Pembelajaran Kooperatif Tipe Two Stay Two Stray terhadap Aktivitas dan Hasil Belajar Siswa tentang IPA di Kelas VI SD Inpres Palupi”. Jurnal Kreatif Tadulako Online. Volume 4 No. 4 Hal 351362.

Nurhadi, M., dkk. 2014. Perbedaan Pengaruh Penerapan Model Pembelajaran Kooperatif Tipe Exampel Non Exampel dan Jigsaw terhadap Prestasi Belajar Pendidikan Kewarganegaraan ( PKN) Ditinjau dari Minat Belajar Siswa SMPN di Kecamatan Undaan Kabupaten Kudus. Jurnal Teknologi Pendidikan Dan Pembelajaran. Volume 2 No.1 Hal 113-126.

Rusman. 2013. Model-model Pembelajaran Mengembangkan
Profesionalisme Guru. Jakarta: PT RajaGrafindo Persada.

Safril, N. 2018. Pengaruh Penerapan Model Experintal Learning Terhadap Hasil Belajar Siswa Materi Pelaku Ekonomi (Eksperimen Di Kelas VIII SMP Negeri 4 Dedai Tahun Pelajaran 2017/2018). Skripsi. STKIP Persada Khatulistiwa Sintang.

Sudjana, N. 2016. Penilaian Hasil Proses Belajar Mengajar. Bandung: PT Remaja Rosdakarya.

Sugiyono. 2013. Metode Penelitian Pendidikan Pendekatan Kuantitatif, Kualitatif, dan R\&D. Bandung: Alfabeta

Sugiyono. 2014. Metode Penelitian Kuantitatif Kualitatif dan $R \& D$. Bandung: Alfabeta.

Sugiyono. 2016. Metode Penelitian Kuantitatif Kualitatif dan $R \& D$. Bandung: Alfabeta.

Sugiyono. 2017. Metode Penelitian Pendidikan Pendekatan Kuantitatif, Kualitatif, dan $R \& D$. Bandung: Alfabeta.

Sukardi. 2013. Metodologi Penelitian Pendidikan. Jakarta: Bumi Aksara

Sukmadinata. 2013. Metode Penelitian Pendidikan. Bandung: PT Remaja Rosdakarya.

Trisnawati, E., dkk. 2016. Pengaruh Model Pembelajaran Kooperatif Tipe Jigsaw terhadap Hasil Belajar Siswa Pada Materi Vektor di Kelas $X$ SMA Negeri 1 Sanggau Ledo. Jurnal Penelitian Fisika dan Aplikasinya (JPFA). Volume 6 No. 2 Hal 51-60. 
Wahyuni, I. dan Munthe, G. Y. 2014. Pengaruh Model Pembelajaran Kooperatif Tipe Two Stay Two Stray (TSTS) terhadap Hasil Belajar Siswa pada Materi Listrik Dinamis pada Siswa SMA. Jurnal Pendidikan Fisika. Volume 3 No. 1 Hal 1-7.

Yusuf, M. 2017. Metode Penelitian Kunatitatif Kualitatif \& Penelitian Gabungan. Jakarta: Kencana 